\title{
DFT Study of Water-Assisted Intramolecular Proton Transfer in the Tautomers of Thymine Radical Cation
}

\author{
Nam Joon Kim \\ Department of Chemistry, Chungbuk National University, Chungbuk 361-763, Korea. E-mail: namikim@chungbukackr \\ Received April 26, 2006
}

\begin{abstract}
Density functional theory calculations are applied to investigate the intramolecular proton transfer in the tautomers of thymine radical cation and its hydrated complexes with one water molecule. The optimized structures and energies for 6 tautomers and 6 transition states of thymine radical cation are calculated at the B3LYP/6-311+ G(d,p) level. It is predicted that the order of relative stability for the keto and enol tautomers of thymine radical cation is the same with that of the neutral thymine tautomers, though the enol tautomers are more stabilized with respect to the di-keto form in the radical cation than in the neutral state. $\Lambda$ new channel of proton transfer from $>\mathrm{C} 5-\mathrm{CHI}_{3}$ of thymine is found to open and have the lowest energy barrier of other proton transfer processes in thymine radical cation. The roles of hydration are also investigated with thymine-water 1 : 1 complex ions. The presence of water significantly lowers the barrier of the proton transfer, which clearly shows the assisting role of hydration even with one water molecule.
\end{abstract}

Key Words : Proton transfer, Tautomer, Thymine radical cation, Thymine-water complex, Hydration

\section{Introduction}

The genetic information is encoded in DNA as the sequence of complimentary DNA base pairs. The DNA base pairs split and reform the base pair with other DNA bases during the replication process. Hence, even the low probability of the base mispairing can be critical and lead to the spontaneous point mutation. ${ }^{1}$ It has long been pointed out that the existence of "rare" tautomeric forms of DNA bases significantly increases the possibility of mispairing. ${ }^{2}$

With labile $\mathrm{H}$ atoms, thymine can exist as noncanonical tautomeric forms. ${ }^{3}$ Although the relative population of the tautomers varies with chemical environment, the canonical di-keto form is known to be dominant in the gas phase as well as in aqueous solution. ${ }^{4,5}$

A large number of theoretical and experimental studies on tautomerism of thymine have been performed. The presence of the di-keto and keto-enol tautomers in aqueous solution was insisted from the fluorescence spectra ${ }^{3}$ The relative stability of the keto and enol tautomers was studied theoretically in the gas phase, ${ }^{6}$ in a microhydrated and in water environment. ${ }^{5}$ The tautomerism of $\mathrm{N}$-methylated pyrimidine bases was also investigated. ${ }^{7}$ Tautomerism of thymine on gold and silver nanoparticle surfaces was analyzed by surface-enhanced Raman scattering and the density functional theory (DFT) calculations. ${ }^{8}$ The roles of water molecules in tautomerization of thymine and uracil have been systematically investigated. ${ }^{9.10}$ Despite all these studies, however, the tautomerism of thymine radical cation has never been studied to our knowledge.

Ionizing radiation is known to cause mutagenic and carcinogenic effects in a mammalian cell with DNA as the primary target. $^{11.12}$ In particular, the radical cations of DNA bases generated by the ionizing radiation directly initiate the breakage of a DNA double-strand, which is one of the most critical cytotoxic DNA lesions. ${ }^{12}$

Since Sevilla ${ }^{13}$ first showed that UV irradiation of thymine at $77 \mathrm{~K}$ in both alkaline and acidic glasses can produce the thymine radical cations, their reactions have been extensively studied in the past decades. ${ }^{14,15}$ The reaction products of the thymine radical cation in the condensed phase have been investigated by electron spin resonance and electron paramagnetic resonance/electron nuclear double resonance. ${ }^{16}$ The formation and decay of the thymine radical cations in solution were directly monitored in nanosecond time scale. ${ }^{17}$ Theoretical calculations on radiation-induced damage of thymine derivatives were also intensively carried out. ${ }^{18}$

In those studies, they insisted that the dominant reaction of thymine radical cation is deprotonation. With the decreased basicity of thymine in its ionic state, thymine radical cation gains considerable acidity ${ }^{14.19}$ and undergoes proton transfer to solvent molecules or to its complementary base in a DNA base pair. ${ }^{20}$ Recently, it was suggested that the ionizationinduced proton transfer occurred in isolated thymineammonia van der Waals clusters. ${ }^{21}$

In this paper, we investigate the intramolecular proton transfer of thymine radical cations leading to the formation of their tautomers, using DFT calculations. The structures of the tautomers of thymine radical cation and the transition states were fully optimized at the B3LYP/6-311++G(d,p) level of theory. The activation energies for intramolecular proton transfer processes were estimated and compared with those of neutral thymine tautomers. The effect of hydration in the proton transfer was also investigated by theoretical calculations on thymine-water $1: 1$ complex ions.

\section{Computational Methods}

The structures at the local minimum or the transition state were fully optimized with DFT employing a hybrid func- 
<smiles></smiles><smiles>[18OH][TeH]</smiles>

Figure 1. Numbering scheme for thymine and water.

tional of B3LYP with a standard $6-311++G(d, p)$ basis set. The stationary points as the local minimum or the transition state were checked by normal mode analysis. No imaginary vibrational frequencies were shown for all of the local minimum structures and only one imaginary frequency was obtained for the transition states. The frequency calculation, zero-point energy ( $\mathrm{ZPE}$ ) correction, and themal energy correction for Gibbs free energy have been performed at this level of theory with the scaling factor of $0.978 .^{22}$

The optimized structures of neutral thymine and thyminewater complexes at the B3LYP/6-3IG(d,p) level were used as initial points in optimizing the structures of thymine radical cation and thymine-water complex ions, respectively. The relaxed potential energy surface scan as a function of the N(1 or 3)-H or CII-H distance (Fig. I) was performed at the B3LYP/6-3IG(d) level to locate the transition state. Then, the full optimization of the transition state was carried out at the B3LYP/6-31I $+\mathrm{G}(\mathrm{d}, \mathrm{p})$ level.

Spin-unrestricted calculations (UB3LYP) were used for all of the radical cations studied here. In the UB3LYP calculations, $\left\langle\mathrm{S}^{2}>\right.$ operator expectation values ranged from 0.757 to 0.771 . All calculations were performed using the GAUSSIAN 03 package. $^{23}$

\section{Results and Discussion}

Rejnek et $a l^{5}$ reported that there were 12 enol tautomers of thymine. However, only four of them are directly produced by intramolecular proton transfer. The production of the other tautomers requires additional $\mathrm{C}-\mathrm{O}$ bond rotation. Since our main interest here is in the tautomerization induced by intramolecular proton tansfer, only the four enol tautomers directly formed through this process are investigated.

Tautomerization of neutral thymine. There are five possible channels of proton transfer: (1) from N1 to $\mathrm{O} 7$ of thymine (T), $\mathrm{T} \rightarrow \mathrm{Tl}$; (2) from N3 to O8 of $\mathrm{T}, \mathrm{T} \rightarrow \mathrm{T} 2$; (3) from $\mathrm{N} 3$ to $\mathrm{O} 7$ of $\mathrm{T}, \mathrm{T} \rightarrow \mathrm{T} 3 ;$ (4) from $\mathrm{N} 3$ to $\mathrm{O} 8$ of $\mathrm{Tl}, \mathrm{T} 1$ $\rightarrow \mathrm{T} 12 ;(5)$ from $\mathrm{NI}$ to $\mathrm{O} 7$ of $\mathrm{T} 2, \mathrm{~T} 2 \rightarrow \mathrm{T} 12$. The optimized geometrical parameters of these tautomers are listed in Table 1. In all these proton transfer processes, two bonds of the pyrimidine ring, which are opposite the transferring proton, are lengthened and the other four are shortened. ${ }^{9}$

The relative energy of the tautomers and the activation free energy of the proton transfer are listed in Table 2 . The relative stability is estimated to be $\mathrm{T}>\mathrm{TI}>\mathrm{T} 2>\mathrm{T} 12>\mathrm{T} 3$, which coincides with previous theoretical results. ${ }^{36}$ The reaction barrier for $\mathrm{T} \rightarrow \mathrm{T} 3$ is the highest and that for $\mathrm{T} 2 \rightarrow$ $\mathrm{T} 12$ is the lowest. The barrier for $\mathrm{T} \rightarrow \mathrm{T} 1$ is a little higher than that for $\mathrm{T} \rightarrow \mathrm{T} 2$. The barriers for the di-enol formation from the keto-enol fonn are lower than those for the ketoenol formation from the di-keto form by $6-12 \mathrm{kcal} / \mathrm{mol}$. This may be due to relatively unstable structures of the keto-enol forms compared with the di-keto form. The energy diagram along the reaction coordinate of the proton transfer is shown in Figure 4(a).

Tautomerization of thymine radical cation. The optimized structures of the tautomers of thymine radical cation are shown in Figure 2. The geometrical parameters are also listed in Table 3. Three bonds of $\mathrm{NI}-\mathrm{C} 2, \mathrm{C} 4-\mathrm{C} 5$ and $\mathrm{C} 5=\mathrm{C} 6$

Table 1. Geometrical parameters of thymine tautomers

\begin{tabular}{|c|c|c|c|c|c|c|c|c|c|c|}
\hline & $\mathrm{T}$ & $\mathrm{T}^{* * a}$ & $\mathrm{~T} 1$ & $\mathrm{~T} 2 *$ & $\mathrm{~T} 2$ & $\mathrm{~T} 3^{*}$ & T3 & $\mathrm{T} 12^{*{ }^{h}}$ & $\mathrm{~T} 21^{* i}$ & $\mathrm{~T} 12$ \\
\hline $\mathrm{N} 1-\mathrm{C} 2$ & $1.387^{d}$ & 1.335 & 1.293 & 1.422 & 1.417 & 1.344 & 1.359 & 1.321 & 1.368 & 1.328 \\
\hline $\mathrm{C} 2-\mathrm{N} 3$ & 1.385 & 1.341 & 1.353 & 1.370 & 1.379 & 1.330 & 1.284 & 1.333 & 1.334 & 1.332 \\
\hline $\mathrm{N} 3-\mathrm{C} 4$ & 1.407 & 1.433 & 1.417 & 1.349 & 1.302 & 1.394 & 1.406 & 1.364 & 1.329 & 1.324 \\
\hline $\mathrm{C} 4-\mathrm{C} 5$ & 1.468 & 1.461 & 1.456 & 1.429 & 1.436 & 1.496 & 1.485 & 1.412 & 1.419 & 1.407 \\
\hline $\mathrm{C} 5=\mathrm{C} 6$ & 1.349 & 1.365 & 1.364 & 1.364 & 1.360 & 1.347 & 1.347 & 1.385 & 1.384 & 1.386 \\
\hline $\mathrm{C} 6-\mathrm{N} 1$ & 1.380 & 1.366 & 1.376 & 1.364 & 1.359 & 1.400 & 1.387 & 1.354 & 1.338 & 1.343 \\
\hline $\mathrm{C} 2=07$ & 1.213 & 1.279 & 1.342 & 1.211 & 1.214 & 1.280 & 1.346 & 1.336 & 1.280 & 1.345 \\
\hline $\mathrm{CA}=08$ & 1.217 & 1.216 & 1.219 & 1.281 & 1.345 & 1.215 & 1.218 & 1.282 & 1.341 & 1.346 \\
\hline $\mathrm{C} 5-\mathrm{C} 11$ & 1.500 & 1.502 & 1.500 & 1.501 & 1.502 & 1.499 & 1.498 & 1.501 & 1.504 & 1.502 \\
\hline $\mathrm{N}_{(\mathrm{T})}-\mathrm{H}^{r}$ & & 1.332 & & 1.328 & & 1.357 & & 1.298 & 1.288 & \\
\hline $\mathrm{O}_{(\mathrm{\top})^{-}} \mathrm{H}^{\prime}$ & & 1.342 & 0.968 & 1.330 & 0.970 & 1.320 & 0.968 & 1.369 & 1.369 & \\
\hline $\mathrm{N} 1 \mathrm{C} 2 \mathrm{O} 7$ & $123.3^{8}$ & 107.9 & 121.5 & 121.0 & 119.6 & 128.6 & 112.9 & 119.8 & 105.4 & 117.6 \\
\hline $\mathrm{N} 3 \mathrm{C} 207$ & 124.1 & 130.3 & 114.1 & 127.7 & 125.4 & 108.4 & 121.6 & 117.1 & 130.7 & 115.5 \\
\hline $\mathrm{N} 3 \mathrm{C} 408$ & 120.3 & 118.9 & 119.9 & 105.9 & 117.7 & 123.6 & 121.2 & 105.4 & 116.7 & 117.4 \\
\hline $\mathrm{C} 5 \mathrm{C} 408$ & 125.1 & 126.5 & 127.2 & 130.7 & 115.8 & 122.8 & 121.7 & 134.1 & 117.2 & 118.6 \\
\hline
\end{tabular}

Transition state of forming the corresponding enol tautomer from $\mathrm{T}$. "Transition state of T1 $\rightarrow \mathrm{T} 12$. "Transition state of T2 $\rightarrow \mathrm{T} 12$, "Bond length in $\mathrm{A}$. 'Distance from $\mathrm{N}$ which donates a proton. Distance from $\mathrm{O}$ which accepts a proton. ${ }^{\text {Bond }}$ angle in degree. 
Table 2. Relative energy, Gibbs free energy and activation free energy for thymine tautomers ${ }^{4}$

\begin{tabular}{crrr}
\hline & $\Delta \mathrm{E}_{0}{ }^{b}$ & $\Delta \mathrm{G}_{298}$ & $\Delta \mathrm{G}_{2} \%^{3+}$ \\
\hline $\mathrm{T}$ & 0.00 & 0.00 & \\
$\mathrm{~T} 1$ & 11.19 & 11.34 & 43.28 \\
$\mathrm{~T} 2$ & 13.08 & 13.17 & 42.01 \\
$\mathrm{~T} 3$ & 18.76 & 18.78 & 47.62 \\
$\mathrm{~T} 12$ & 14.17 & 14.38 & $36.87^{i}$ \\
& & & $35.95^{\circ}$ \\
\hline
\end{tabular}

"Energy in hcal/mol. "Relative energy with zero point energy correction. "Aclivation Iree energy of forming the corresponding enol tautomer from $\mathrm{T}$ at $\mathrm{l}$ alm and $298.15 \mathrm{~K}$. "Activation free energy of $\mathrm{Tl} \rightarrow \mathrm{Tl} 2$. Activation free energy of $\mathrm{T} 2 \rightarrow \mathrm{T} 12$.
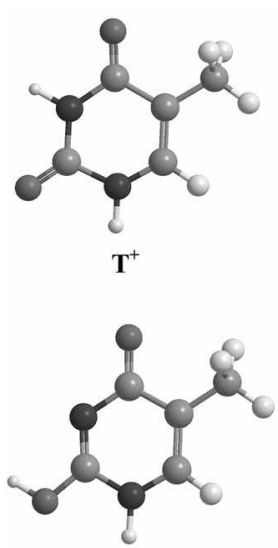

$\mathbf{T 3}^{+}$
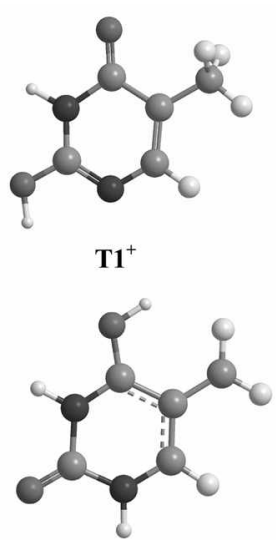

$\mathbf{T 4}^{+}$
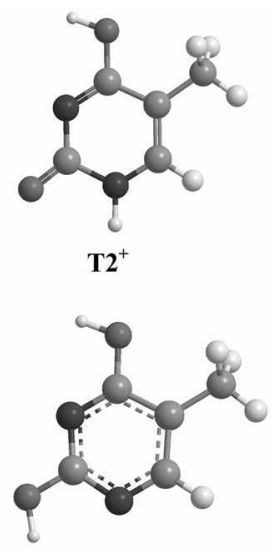

$\mathbf{T 1 2}^{+}$
Figure 2. The structures of the tautomers of thymine radical cation optimized at the B3LYP/6-311+ G(d,p) level. in the pyrimidine ring are lengthened in $T^{+}$compared with those in $\mathrm{T}$, while the other bonds are shortened. The N1-C2 increases the most by $0.062 \AA$ and the $\mathrm{C} 6-\mathrm{N} 1$ decreases the most by $0.056 \AA$. Two $\mathrm{C}=\mathrm{O}$ and $\mathrm{C} 5-\mathrm{Cl} 1$ bonds become shorter in $\mathrm{T}^{+}$. Both $\mathrm{C}=\mathrm{O}$ bonds are lengthened following the proton transfer.

The relative energies and the activation free energies are listed in Table 4 . The energy diagram along the reaction coordinate is also shown in Figure 4(b). Although the relative energies of $\mathrm{Tl}^{+}, \mathrm{T}^{+}, \mathrm{T}^{+}$and $\mathrm{T}_{1} 2^{+}$with respect to $\mathrm{T}^{+}$become smaller, the order of the relative stability $\left(\mathrm{TI}^{+}>\right.$ $\left.\mathrm{T} 2^{+}>\mathrm{Tl} 2^{+}>\mathrm{T}^{+}\right)$is the same with that of the tautomers of neutral thymine. $\mathrm{TI}^{+}$is the most stabilized and the barrier of $\mathrm{T}^{+} \rightarrow \mathrm{TI}^{+}$also becomes lower than that of $\mathrm{T} \rightarrow \mathrm{Tl}$ by 6.35 $\mathrm{kcal} / \mathrm{mol}$. However, the other proton transfer processes in $\mathrm{T}^{+}$ have the higher barrier than the corresponding processes in T.

The most interesting finding is that there is a new channel of proton transfer, $\mathrm{T}^{+} \rightarrow \mathrm{T}^{+}$. This channel is predicted not to open in neutral thymine. $\mathrm{T}^{+}$is the most stable of other tautomers of $\mathrm{T}^{+}$and the barrier for $\mathrm{T}^{+} \rightarrow \mathrm{T}^{+}$is also the lowest of other proton transfer processes in $\mathrm{T}^{+}$. This indicates that the intramolecular proton transfer through this channe] is the most favored in $\mathrm{T}^{+}$. This also goes in parallel with the earlier condensed phase study which found the deprotonation at $\mathrm{Cl} 1-\mathrm{H}$ was the main reaction channel for the thymine radical cation in anhydrous thymine crystals. ${ }^{162+4}$

Water-assisted proton transfer in thymine radical cation. The optimized structures of thymine-water $1: 1$ complex jons, their tautomers and the transition states are shown in Figure 3. The geometrical parameters of the transition states are listed in Table 5. The relative energies and the activation free energies are also in Table 6 . The

Table 3. Geometrical parameters of the tautomers of thymine radical cation

\begin{tabular}{|c|c|c|c|c|c|c|c|c|c|c|c|c|}
\hline & $\mathrm{T}^{\prime}$ & $\mathrm{T} 1^{\prime * *}$ & $\mathrm{~T}^{\prime}$ & $\mathrm{T} 2 *$ & $\mathrm{~T} 2{ }^{\prime}$ & T3* & T3 & T4* & T4 & $\mathrm{T} 12^{\prime} * k^{h}$ & $\mathrm{~T} 21^{* * i}$ & $\mathrm{~T} 12^{\prime}$ \\
\hline $\mathrm{N} 1-\mathrm{C} 2$ & 1.449 & 1.391 & 1.349 & 1.483 & 1.449 & 1.393 & 1.405 & 1.419 & 1.393 & 1.376 & 1.406 & 1.375 \\
\hline $\mathrm{C} 2-\mathrm{N} 3$ & 1.372 & 1.329 & 1.332 & 1.357 & 1.364 & 1.320 & 1.277 & 1.410 & 1.419 & 1.319 & 1.330 & 1.332 \\
\hline $\mathrm{N} 3-\mathrm{CA}$ & 1.402 & 1.432 & 1.425 & 1.342 & 1.303 & 1.385 & 1.392 & 1.348 & 1.335 & 1.364 & 1.315 & 1.312 \\
\hline $\mathrm{CA}-\mathrm{C} 5$ & 1.494 & 1.491 & 1.471 & 1.460 & 1.456 & 1.513 & 1.488 & 1.458 & 1.438 & 1.442 & 1.468 & 1.459 \\
\hline $\mathrm{C} 5=\mathrm{C} 6$ & 1.407 & 1.417 & 1.420 & 1.417 & 1.408 & 1.411 & 1.403 & 1.380 & 1.401 & 1.434 & 1.424 & 1.430 \\
\hline $\mathrm{C} 6-\mathrm{N} 1$ & 1.324 & 1.315 & 1.319 & 1.319 & 1.320 & 1.337 & 1.333 & 1.347 & 1.351 & 1.311 & 1.308 & 1.307 \\
\hline $\mathrm{C} 2=07$ & 1.194 & 1.249 & 1.299 & 1.195 & 1.208 & 1.254 & 1.315 & 1.192 & 1.195 & 1.296 & 1.257 & 1.298 \\
\hline $\mathrm{CA}=08$ & 1.203 & 1.200 & 1.206 & 1.257 & 1.316 & 1.208 & 1.222 & 1.253 & 1.306 & 1.258 & 1.309 & 1.308 \\
\hline $\mathrm{C} 5-\mathrm{C} 11$ & 1.470 & 1.475 & 1.474 & 1.471 & 1.477 & 1.468 & 1.475 & 1.437 & 1.407 & 1.474 & 1.477 & 1.473 \\
\hline $\mathrm{N}_{(\mathrm{TI}}-\mathrm{H}$ & & 1.325 & & 1.345 & & 1.378 & & & & 1.343 & 1.307 & \\
\hline $\mathrm{O}_{(\mathrm{TN}-\mathrm{H}}$ & & 1.352 & & 1.356 & & 1.343 & & 1.358 & & 1.350 & 1.351 & \\
\hline $\mathrm{C} 11-\mathrm{H}^{\prime \prime}$ & & & & & & & & 1.374 & & & & \\
\hline $\mathrm{N} 1 \mathrm{C} 2 \mathrm{O} 7$ & 119.5 & 105.3 & 119.5 & 117.6 & 116.9 & 126.3 & 110.9 & 122.7 & 125.6 & 118.3 & 103.4 & 116.3 \\
\hline $\mathrm{N} 3 \mathrm{C} 2 \mathrm{O} 7$ & 127.6 & 133.3 & 116.8 & 130.5 & 126.1 & 110.9 & 125.5 & 123.9 & 122.9 & 119.3 & 131.4 & 116.4 \\
\hline $\mathrm{N} 3 \mathrm{CAO} 8$ & 122.3 & 120.5 & 120.2 & 107.9 & 120.5 & 125.3 & 121.2 & 125.1 & 114.2 & 106.1 & 120.0 & 120.3 \\
\hline $\mathrm{C} 5 \mathrm{C} 408$ & 122.5 & 123.9 & 125.5 & 129.2 & 115.1 & 120.6 & 119.6 & 115.3 & 125.3 & 132.1 & 115.1 & 116.4 \\
\hline
\end{tabular}

"Transition state of forming the corresponding enol tautomer from $\mathrm{T}^{+}$. ${ }^{h}$ Transition state of $\mathrm{T} 1^{+} \rightarrow \mathrm{T} 12^{+}$. ${ }^{c} \mathrm{Transition}$ state of $\mathrm{T} 2^{+} \rightarrow \mathrm{Tl} 2^{+}$. "Distance from C11 to the prolon which iransfers to $\mathrm{O}_{8}$. 
<smiles>CC(C)C1OC(C)C(C)C(C)C1C(C)C</smiles>

$\&$

$\mathbf{T}^{+}-\mathbf{W 1}$

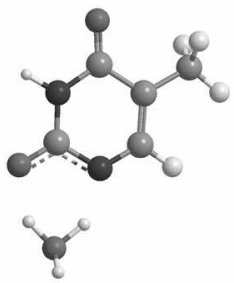

$\mathbf{T} 1^{+}-\mathbf{W}^{*}$

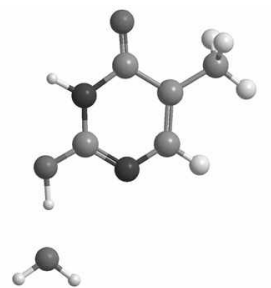

$\mathbf{T 1}^{+}-\mathrm{W}$

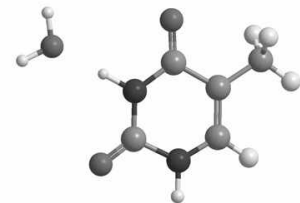

$\mathbf{T}^{+}-\mathbf{W} 2$

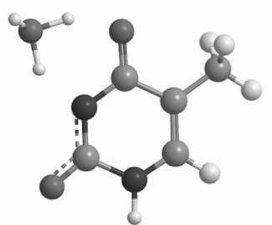

$\mathbf{T 2}^{+}-\mathrm{W}^{*}$

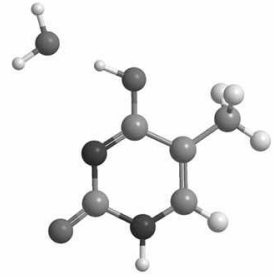

$\mathrm{T2}^{+}-\mathrm{W}$

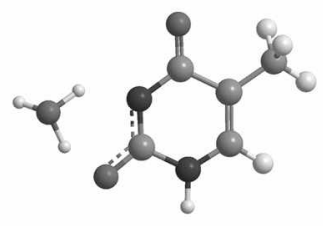

$\mathrm{T3}^{+}-\mathrm{W}^{*}$

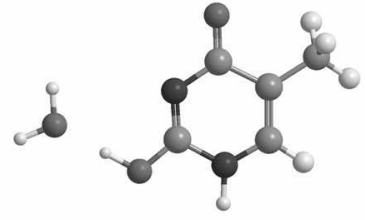

$\mathbf{T 3}^{+}-\mathrm{W}$

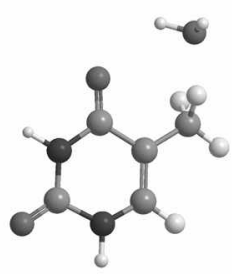

$\mathbf{T}^{+}-\mathbf{W 3}$

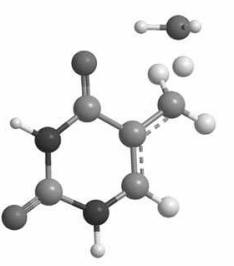

$\mathrm{T4}^{+}-\mathrm{W}^{*}$

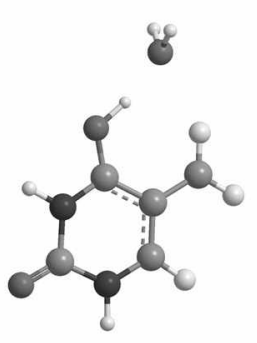

$\mathbf{T} \mathbf{4}^{+}-\mathbf{W}$

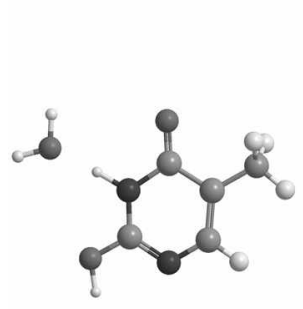

$\mathbf{T 1}+\mathbf{W 2}$

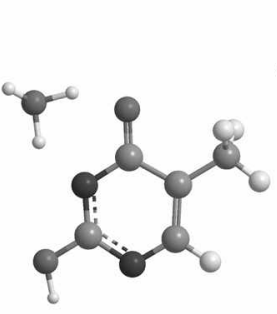

$\mathrm{T12}^{+}-\mathrm{W} 2 *$

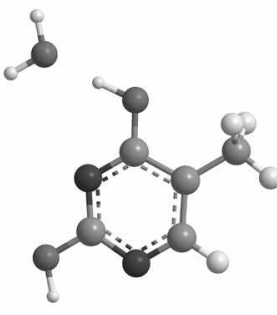

T12 + W2

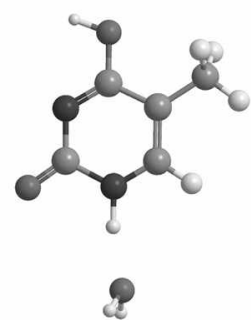

$\mathbf{T} 2^{+}-\mathbf{W 1}$

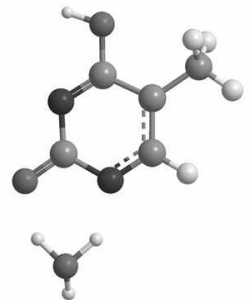

$\mathrm{T} 21^{+}-\mathrm{W} 1^{*}$

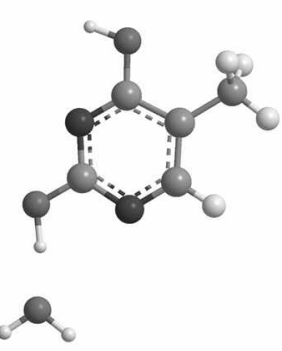

T21 + W1

Figure 3. The structures of hydrated thymine radical cations, their enol taltomers and the transition states optimized at the B3LYP/6$311+G(d, p)$ level. $T^{+}-W 3$ is optimized at the B3LYP/6-31G(d,p) level. See the text.

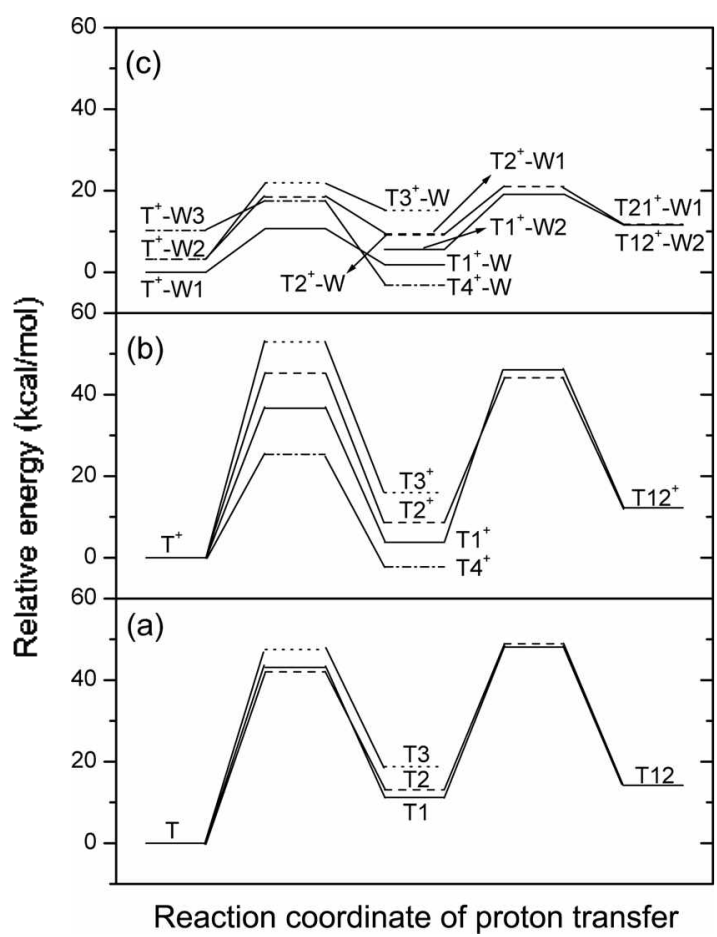

Figure 4. Energy diagram of the relative energies $\left(\Delta \mathrm{E}_{0}\right)$ for the tautomers and the transition states of (a) $\mathrm{T}$, (b) $\mathrm{T}^{+}$, and (c) hydrated $\mathrm{T}^{+}$along the reaction coordinate of proton transfer. energy diagram along the reaction coordinate is shown in Figure 4(c).

Note that $T^{-}-W 3$ in Figure 3 is the fully optimized structure at the B3LYP/6-31G(d,p) rather than the B3LYP/6$311++G(d, p)$ level. $T^{+}-W 3$ converged into the structure where the water molecule was hydrogen-bonded to the $\pi$ electrons of the pyrimidine ring rather than to the $\mathrm{C} 11-\mathrm{H}$ and O8 during the optimization process at the B3LYP/6$311++G(d, p)$ level. Therefore, following geometry optimization at the B3LYP/6-3IG(d,p) level, only the single point energy calculation of $\mathrm{T}^{+}-\mathrm{W} 3$ was performed at the B3LYP/ $6-31 \mathrm{I}+\mathrm{G}(\mathrm{d}, \mathrm{p})$ level. The thermal correction for the Gibbs free energy as well as the zero point energy correction was done with the frequencies calculated at the B3LYP/6$31 \mathrm{G}(\mathrm{d}, \mathrm{p})$ level with the scale factor of $0.961{ }^{25}$

One water molecule can bind to $\mathrm{T}^{+}$in three different regions and form $\mathrm{T}^{+}-\mathrm{W} 1$ or $\mathrm{T}^{+}-\mathrm{W} 2$ or $\mathrm{T}^{+}-\mathrm{W} 3$ (Fig. 3). The relative stability is $\mathrm{T}^{+}-\mathrm{WI}>\mathrm{T}^{+}-\mathrm{W} 2>\mathrm{T}^{+}-\mathrm{W} 3$. Each complex ion can form tautomers through proton transfer processes involving the water molecule as a proton acceptor and then donor. The relative stability of the hydrated tautomers is $\mathrm{T} 4^{+}-\mathrm{W}>\mathrm{Tl}^{+}-\mathrm{W}>\mathrm{T} 2^{+}-\mathrm{W}>\mathrm{T} 3^{+}-\mathrm{W}$, which is the same as that of the unhydrated tautomers of $\mathrm{T}^{+}\left(\mathrm{T}^{+}>\mathrm{TI}^{+}>\mathrm{T}^{+}>\right.$ $\mathrm{T}^{+}$). However, the barriers of forming these hydrated tautomers are much smaller, which are only one third of the barrier heights for the corresponding processes in $\mathrm{T}^{+}$. 
Table 4. Relative encrgy, Gibbs free energy, and activation frec energy of the tautomers of thymine radical cation

\begin{tabular}{|c|c|c|c|}
\hline & $\Delta \mathrm{E}_{i}$ & $\Delta G_{2088}$ & $\Delta G_{2}=8^{t b}$ \\
\hline $\mathrm{T}^{\prime}$ & 0.00 & 0.00 & \\
\hline $\mathrm{T} 1^{\prime}$ & 3.76 & 3.44 & 36.93 \\
\hline $\mathrm{T} 2$ & 8.63 & 9.21 & 45.67 \\
\hline T3 & 16.00 & 16.41 & 53.39 \\
\hline T4 & -2.25 & -1.27 & 26.83 \\
\hline $\mathrm{T} 12^{\circ}$ & 12.26 & 12.68 & $\begin{array}{l}42.83^{c} \\
35.57^{d}\end{array}$ \\
\hline
\end{tabular}

"Energy in kcal/mol. ${ }^{\text {H}}$ Activation free energy of forming the corresponding enol tautomer from $\mathrm{T}^{+}$at 1 atm and $298.15 \mathrm{~K}$. ${ }^{c}$ Activation free energy for $\mathrm{Tl}^{+} \rightarrow \mathrm{T} 12^{+}$. Activation free energy for $\mathrm{T}^{+} \rightarrow \mathrm{T} 12^{+}$.

This clearly shows the assisting role of hydration in the proton transfer processes even with one water molecule, which have also been reported in previous theoretical studies. ${ }^{9.10 .26}$

The formation of $\mathrm{T}^{+}-\mathrm{W}$ from $\mathrm{T}^{+}-\mathrm{W} 3$ has the lowest barrier, as is the case of $\mathbf{T}^{+} \rightarrow \mathrm{T}^{+}$. However, since $\mathbf{T}^{+}$-W3 is at higher energy than $\mathrm{T}^{+}-\mathrm{W} 1$ and $\mathrm{T}^{+}-\mathrm{W} 2$, the initial population of $\mathrm{T}^{+}-\mathrm{W} 3$ will be small. Hence, the contribution of this channel in the tautomerization of hydrated $\mathrm{T}^{+}$is expected to be less than that of the reaction channel of $\mathrm{T}^{+}$$\mathrm{W} 1 \rightarrow \mathrm{T}^{+}-\mathrm{W}$ that has a little higher energy barrier. This is supported by the experimental observation that deprotonation in the N1 site is a dominant reaction channel of pyrimidine radical cations in aqueous solution. ${ }^{17}$

The barrier heights for the di-enol formation from $\mathrm{Tl}^{+}-\mathrm{W} 2$
Table 6. Relative energy, Gibbs free energy and activation free energy for the tautomers of hydrated thymine radical cation ${ }^{\text {t }}$

\begin{tabular}{|c|c|c|c|}
\hline & $\Delta \mathrm{E}_{0}$ & $\Delta \mathrm{G}_{298}$ & $\Delta \mathrm{G}_{2} \mathrm{gs}^{\text {th }}$ \\
\hline $\mathrm{T}^{-}-\mathrm{W1}$ & 0.00 & 0.00 & \\
\hline$T^{-}-W 2$ & 3.17 & 2.98 & \\
\hline$T^{-}-W_{3}$ & 10.27 & 11.24 & \\
\hline $\mathrm{Tl}^{-}-\mathrm{W}$ & 1.83 & 1.77 & \\
\hline $\mathrm{T} 2^{-}-\mathrm{W}$ & 9.20 & 9.59 & \\
\hline$T 3^{-}-W$ & 15.19 & 15.34 & \\
\hline $\mathrm{T}^{-}-\mathrm{W}$ & -3.18 & -1.43 & \\
\hline $\mathrm{T} 1^{-}-\mathrm{W} 2$ & 5.63 & 5.60 & \\
\hline $\mathrm{T} 2^{-}-\mathrm{W} 1$ & 9.44 & 9.95 & \\
\hline $\mathrm{T} 12^{-}-\mathrm{W} 2$ & 11.62 & 11.91 & \\
\hline $\mathrm{T} 21^{-}-\mathrm{W} 1$ & 11.76 & 12.08 & \\
\hline $\mathrm{T}^{-}-\mathrm{W} 1 \rightarrow \mathrm{T}^{-}-\mathrm{W}^{*}$ & & & 13.00 \\
\hline $\mathrm{T}^{-}-\mathrm{W} 2 \rightarrow \mathrm{T} 2^{-}-\mathrm{W}^{*}$ & & & 17.95 \\
\hline $\mathrm{T}^{-}-\mathrm{W}_{2} \rightarrow \mathrm{T}^{-}-\mathrm{W}^{*}$ & & & 21.08 \\
\hline $\mathrm{T}^{-}-\mathrm{W}_{3} \rightarrow \mathrm{T}^{-}-\mathrm{W}^{*}$ & & & 9.13 \\
\hline $\mathrm{T}^{-}-\mathrm{W} 2 \rightarrow \mathrm{T} 12^{-}-\mathrm{W} 2^{*}$ & & & 15.92 \\
\hline $\mathrm{T} 2^{-}-\mathrm{W} 1 \rightarrow \mathrm{T} 21^{-}-\mathrm{W} 1^{*}$ & & & 13.71 \\
\hline
\end{tabular}

"Energy in kcal/mol. ${ }^{b}$ Activation free energy of proton transfer at 1 atm and $298.15 \mathrm{~K}$.

and $\mathrm{T}^{+}-\mathrm{W} 1$ are also three times lower than those for the same processes from $\mathrm{Tl}^{+}$and $\mathrm{T}^{+}$. The barrier of the di-enol formation from $\mathrm{Tl}^{+}-\mathrm{W} 2$ is a little higher than that of $\mathrm{T}^{+}-$ W1. This is in line with the observation that the proton transfer from $\mathrm{N} 3$ to $\mathrm{O} 8\left(\mathrm{~T}^{+}-\mathrm{W} 2 \rightarrow \mathrm{T}^{+}-\mathrm{W}\right)$ needs higher energy than that from $\mathrm{N} 1$ to $\mathrm{O} 7\left(\mathrm{~T}^{+}-\mathrm{W} 1 \rightarrow \mathrm{Tl}^{+}-\mathrm{W}\right)$.

Table 5. Geometrical parameters of the transition states for tautomerization of thymine-amonia $1: 1$ complex ions

\begin{tabular}{|c|c|c|c|c|c|c|}
\hline & $\mathrm{T}^{-}-\mathrm{W}^{*}$ & $\mathrm{~T} 2^{-}-\mathrm{W}^{*}$ & $\mathrm{~T}^{-}-\mathrm{W}^{*}$ & $\mathrm{~T}^{-}-\mathrm{W}^{*}$ & $\mathrm{~T} 12^{-}-\mathrm{W} 2^{*}$ & $\mathrm{~T} 21^{-}-\mathrm{W} 1^{*}$ \\
\hline $\mathrm{N} 1-\mathrm{C} 2$ & 1.410 & 1.463 & 1.438 & 1.417 & 1.374 & 1.423 \\
\hline $\mathrm{C} 2-\mathrm{N} 3$ & 1.359 & 1.352 & 1.320 & 1.392 & 1.315 & 1.361 \\
\hline N3-C4 & 1.407 & 1.353 & 1.381 & 1.380 & 1.376 & 1.302 \\
\hline $\mathrm{C} 4-\mathrm{C} 5$ & 1.478 & 1.486 & 1.498 & 1.485 & 1.468 & 1.452 \\
\hline $\mathrm{C} 5=\mathrm{C} 6$ & 1.414 & 1.406 & 1.406 & 1.391 & 1.421 & 1.419 \\
\hline $\mathrm{C} 6-\mathrm{N} 1$ & 1.317 & 1.320 & 1.325 & 1.342 & 1.312 & 1.310 \\
\hline $\mathrm{C} 2=07$ & 1.233 & 1.206 & 1.248 & 1.196 & 1.310 & 1.241 \\
\hline $\mathrm{CA}=08$ & 1.207 & 1.250 & 1.218 & 1.225 & 1.248 & 1.320 \\
\hline $\mathrm{C} 5-\mathrm{C} 11$ & 1.476 & 1.473 & 1.473 & 1.421 & 1.476 & 1.478 \\
\hline $\mathrm{N}_{(\mathrm{Tn})}-\mathrm{H}^{\mu}$ & 1.601 & 1.602 & 1.713 & & 1.643 & 1.588 \\
\hline $\mathrm{O}_{(\mathrm{II})}-\mathrm{H} 17^{b}$ & 1.577 & 1.501 & 1.446 & 1.815 & 1.518 & 1.554 \\
\hline $\mathrm{C} 11-\mathrm{H}^{*}$ & & & & 1.422 & & \\
\hline $016-\mathrm{H}^{d}$ & 1.051 & 1.049 & 1.026 & 1.226 & 1.039 & 1.054 \\
\hline $016-\mathrm{H} 17^{\circ}$ & 1.032 & 1.054 & 1.072 & 0.991 & 1.049 & 1.037 \\
\hline O16-H18 & 0.970 & 0.969 & 0.969 & 0.970 & 0.970 & 0.970 \\
\hline $\mathrm{N} 1 \mathrm{C} 2 \mathrm{O} 7$ & 119.3 & 116.2 & 115.2 & 122.2 & 116.1 & 116.7 \\
\hline $\mathrm{N} 3 \mathrm{C} 2 \mathrm{O} 7$ & 122.3 & 127.7 & 125.6 & 124.9 & 117.1 & 121.2 \\
\hline $\mathrm{N} 3 \mathrm{C} 408$ & 121.5 & 121.2 & 122.4 & 121.1 & 119.8 & 120.4 \\
\hline $\mathrm{C5C} 408$ & 124.1 & 118.7 & 119.3 & 123.2 & 120.9 & 115.7 \\
\hline $\mathrm{H} 17016 \mathrm{H} 18$ & 113.4 & 114.1 & 114.7 & 110.7 & 114.1 & 113.4 \\
\hline
\end{tabular}

"Distance from $\mathrm{N}$ which donates a proton. 'Distance from $\mathrm{O}$ which accepts a proton. ${ }^{\circ}$ Distance from $\mathrm{C} 11$ to the proton which transfers to the water. "Bond length between 016 and the proton which transfers from thymine radical cation. "III7 is the proton that transfers to 07 or 08 . 


\section{Conclusions}

DFT calcultions have been performed to explore intramolecular proton transfer in thymine radical cation. By analyzing geometric parameters, energies and activation free energies of the processes, we reach the following conclusions.

1. The relative stability of the tautomers of thymine radical cation is $\mathrm{T}^{+}>\mathrm{T}^{+}>\mathrm{T}^{+}>\mathrm{T}_{1} 2^{+}>\mathrm{T}^{+}$, which is the same as that of neutral thymine tautomers. However, the enol tautomers are more stabilized with respect to the di-keto form in the radical cation than in the neutral state. The hydration of thymine radical cation further reduces the energy gap between the di-keto and the enol forms.

2. A new channel of proton transfer from $\mathrm{C} 11$ to $\mathrm{O} 8$ of $\mathrm{T}^{+}$, $\mathrm{T}^{+} \rightarrow \mathrm{T}^{+}$, opens in thymine radical cation. This channel has the lowest energy barrier of other proton transfer processes in $\mathrm{T}^{+}$, which is estimated to be $26.83 \mathrm{kcal} / \mathrm{mol}$. $\mathrm{T}^{+}$is also most stable of other tautomers of thymine radical cation studied here.

3 . The hydration of thymine radical cation by one water molecule significantly lowers the barrier for proton transfer. The barrier heights are only one third of those for the corresponding processes of $\mathrm{T}^{+}$.

4. The formation of the di-enol tautomer from the ketoenol tautomers has a little lower barrier than the formation of the keto-enol tautomers from the di-keto tautomer. For example, the barrier heights for $\mathrm{T} 1 \rightarrow \mathrm{T} 12$ and $\mathrm{T} 2 \rightarrow \mathrm{T} 12$ are lower than those for $\mathrm{T} \rightarrow \mathrm{T} 2$ and $\mathrm{T} \rightarrow \mathrm{T} 1$, respectively. This is attributed to less stable structures of the keto-enol forms than the di-keto form. The difference, however, gets smaller in the radical cation and also in the hydrated ion. This can be explained by the stabilization of the keto-enol forms in the radical cation and in the hydrated ion.

Acknowledgements. This work was supported by the Korea Research Foundation Grant (KRF-2003-003-C00067).

\section{References}

1. Watson, J. D.; Crick, F. H. C. Nature 1953, 171, 737.

2. Lowdin, P. O. Ad, Quantum. Chem. 1965, 2, 213; Topal, M. D.; Fresco, J. R. Nattire 1976, 263, 285; Lee, G.-Y. Bull. Korean Chem. Soc. 2006, $27,419$.

3. Morsy, M. A.; Al-Somali, A. M.; Suwaiyan, A. J. Ph: Chem. B $1999,103,11205$.

4. Colarusso, P.; Zhang, K.; Guo, B.; Bernath, P. F. Chem. Phys. Lett. 1997, 269, 39; Civcir, P. Ü. J. Mol. Siruct. (Theochem 2000, 532, 157.

5. Rejnek, J.; Hanus, M.; Kabelác, M.; Ryjâcek, F.; Hobza, P. Phys.
Chem. Chem. Phys. 2005, 7, 2006.

6. Piacenza, M.; Grimme, S. J. Comput. Chem. 2003, 25, 83.

7. Yekeler, H. J. Mol. Siruct. (Theochent) 2005, 713,201.

8. Cho, K.-H.; Choo, J.; Joo, S.-W. J. Mol. Struct. 2005, 738, 9.

9. Hu, X.; Li, H.; Liang, W.; Han, S. J. Phys. Chem, B 2005, 109, 5935.

10. Markova, N.; Enchev, V; Timtheva, I. J. Phys. Chem. A 2005 , $109,1981$.

11. von Sonntag, C. The Chenical Basis of Radiation Biolog;, Taylor and Francis: London, 1987; Yan, M.; Becker, D.; Summerfield, S.; Renke, P.; Sevilla, M. D. J. Phys. Chem, 1992, 96, 1983.

12. Litle, J. B. Carcinogenesis 2000, 21, 397.

13. Sevilla, M. D. J. Phys. Chem. 1971, 75,626.

14. Steenken, S. Free Rad. Res. Connts. 1992, 16,349.

15. Sevilla, M. D.; Paemel, C. V.; Zorman, G. J. Phys. Chem. 1972, 76, 3577; Wagner, J. R, van Lier, J. E.; Johnston, L. J. Photochem. Photobiol. 1990, 52, 333; Deeble, D. J.; Schuchmann, M. N.; Steenken, S.; von Sonntag, C. J. Phy. Chem. 1990, 94, 8186.

16. Close, D. M. Radiat. Res. 1993, 135, 1.

17. Geimer, J.; Brede, O.; Beckert, D. Chem. Phos. Lett. 1997, 276, 411 .

18. Wetmore, S. D.; Himo, F.; Boyd, R. J.; Erikssson, L. A. J. Phys, Chem, B 1998, 102, 7484; Close, D.; Forde, G.; Gorb, L.; Leszczynski, J. Struct. Chen. 2003, 14,451; Naumov, S.; Barthel, A.; Reinhold, J.; Dietz, F.; Geimer, J.; Beckert, D. Phys. Chem. Chem. Phss. 2000, 2, 4207.

19. Hwang, S.; Jang. Y. H.; Chung. D. S. Bull Korean Chent. Soc. $2005,26,585$.

20. Steenken, S. Chem, Rev, 1989, 89, 503,; Choi, S.-S.; So, H.-Y. Bull. Korean Chem. Soc. 2004, 25, 1538.

21. Kim, N. J.; Kim, H. M.; Kim, S. K. submitted.

22. Kang, Y. K. J. Mol. Strict. (Theochem) 2001, 546, 183.

23. Frisch, M. J.; Trucks, G. W.; Schlegel, H. B.; Scuseria, G. E.; Robb, M. A.; Cheeseman, J. R.; Montgomery, J. A. Jr.; Vreven, T.; Kudin, K. N.; Burant, J. C.; Millam, J. M.; Iyengar, S. S.; Tomasi, J.; Barone, V.; Mennucci, B.; Cossi, M.; Scalmani, G.; Rega, N.; Petersson, G. A.; Nakatsuji, H.; Hada, M.; Ehara, M.; Toyota, K.; Fukuda, R.; Hasegawa, J.; Ishida, M.; Nakajima, T.; Honda, Y.; Kitao, O.; Nakai, H.; Klene, M.; Li, X.; Knox, J. E.; Hratchian, H. P.; Cross, J. B.; Adamo, C.; Jaramillo, J.; Gomperts, R.; Straumann, R. E.; Yazyev, O.; Austin, A. J.; Cammi, R.; Pomelli, C.; Ochterski, J. W.; Ayala, P. Y.; Morokuma, K.; Voth, G. A.; Salvador, P.; Dannenberg, J. J.; Zakrzewski, V. G.; Dapprich, S.; Daniels, A. D.; Strain, M. C.; Farkas, O.; Malick, D. K.; Rabuck, A. D.; Raghavachari, K.; Foresman, J. B.; Ortiz, J. V.; Cui, Q.; Baboul, A. G.; Clifford, S.; Cioslowski, J.; Stefanov, B. B.; Liu, G; Liashenko, A.; Piskorz, P.; Komaromi, I.; Martin, R. L.; Fox, D. J.; Keith, T.; Al-Laham, M. A.; Peng, C. Y.; Nanayakkara, A.; Challacombe, M.; Gill, P. M. W.; Johnson, B.; Chen, W.; Wong, M. W.; Gonzalez, C; Pople, J. A. Gatssian 03, Revision C.02; Gaussian, Inc.: Wallingford, CT, 2004.

24. Bernhard, W. A.; Barmes, J.; Mercer, K. R.; Mroczka, N. Radiat. Res. 1994, 140, 199.

25. Irikura, K. K.; Johnson III, R. D.; Kacker, R. N. J. Phys. Chem. A $2005,109,8430$.

26. Gu, J.; Leszczynski, J. J. Phss. Chen. A 1999, J03, 2744. 